\title{
Analysis of The Effects of Open Place Performance on Users' Satisfaction Using Post-Occupancy Evaluation
}

\author{
Doruk Görkem Özkan ${ }^{1}$, Duygu Akyol 2 ๑ \\ 1 Assist. Prof. Dr., Faculty of Foresty, Karadeniz Technical UniversityTrabzon, Turkey. (Principal contact for editorial \\ correspondence), Email: dorukgorkemozkan@gmail.com \\ ${ }^{2}$ Res. Asst., Faculty of Foresty, Karadeniz Technical University,Trabzon, Turkey, Email: duyguakyol@ktu.edu.tr
}

\begin{abstract}
Purpose

The current article aimed to investigate the effects of functional, social, and perceptual performance dimensions of coastal open place environmental attributes on place satisfaction. In this context, it aimed to develop suggestions for increasing the place performance levels in order to improve the place satisfaction.

\section{Design/Methodology/Approach}

The general framework of the research design was determined by evaluating the functional, social and perceptual features of the place by the users (using post-occupancy evaluation method) and determining the place performance and place satisfaction. Survey questions within this scope; It is structured under two main headings: functional, social and perceptual features of the place and place satisfaction. Each item was measured on a 5-point Likert scale $(1=$ strongly disagree, $5=$ strongly agree). Participants were randomly selected from the Arsin coastal park users. The surveys were conducted with 243 people on weekdays and weekends.
\end{abstract}

\section{Findings}

The study findings demonstrated that there was a positive and significant correlation between the spatial performance level and place satisfaction using the developed model. It was observed that the environmental factors that affected the place satisfaction included functional, social, and perceptual factors, respectively. It was determined that socio-demographic factors did not affect place satisfaction, while the frequency of occupancy had a positive impact on place satisfaction. Research Limitations/Implications

The present study focused on the functional, social, and perceptual dimensions of environmental properties. Thus, considering the diversity of environmental properties, it could not be claimed that the present study methodology and findings revealed all environmental dimensions that affect satisfaction.

\section{Social and Practical Implications}

In the present study, spatial performance data were obtained with post-occupancy evaluation and the factors that affected the satisfaction levels with Arsin Coastal Park (ACP) were investigated. Thus, the present study findings could be considered as very important for urban designers, planners, and administrators.

\section{Originality/Value}

There are studies in the literature that evaluated urban open place satisfaction. However, there are no studies that investigated the effects of open place performance criteria on place satisfaction using the post-occupancy evaluation (POE) method.

Keywords: Urban open place, place attributes, place satisfaction, post-occupancy evaluation 


\section{INTRODUCTION}

Cities consist of physical structures and defined spaces. These defined or undefined urban spaces are described as urban open places. Urban open places assume various urban functions such as environmental, social, economic, and health-related functions. According to Carmona (2010), the importance of urban open places derives from the fulfillment of individual needs and special interaction opportunities they provide for urban individuals or groups. In urban design literature, the discussions on the requirement for urban open places and their functions continue. In recent years, research focused on urban open places in coastal cities and the coastal transformation and renovations were analyzed based on the users. Especially touristic and recreational transformation and renovation projects aim to meet user requirements and create user satisfaction with their functional, social, and perceptual attributes.

Turkish cities develop and change rapidly and increasing population with and construction lead to a decrease in urban open places. Especially in coastal Turkish cities, these changes lead to an increasing number of landfills to meet urban open place requirements. Within the scope of this goal, these areas, which are designed and constructed to meet the need for open places in city centers;

- $\quad$ The functional, social and perceptual possibilities it offers

- $\quad$ Level of meeting user needs and requirements

- $\quad$ Open place performance level

There were issues that needed to be focused and evaluated. In this context, the design and construction process has been completed and these places, which have met with the user, should be evaluated with the post-occupancy evaluation method. At this point, the place performance level and place satisfaction, which is the level of meeting the user's needs, can be determined by evaluating the place by the users.

Fort his purpose, the present study focused on the analysis of the functional, social and perceptual attributes of the Arsin landfill area, one of the transformations and renovations conducted in Trabzon city, using the post-occupancy evaluation method and investigated the effects of these attributes on user satisfaction. Thus, urban open place properties, spatial performance, and user satisfaction concepts were discussed based on the post-occupancy evaluation method.

\section{LITERATURE REVIEW}

One of the most important urban dimensions is the "change and transformation" dimension since the construction of initial cities. Each city was affected and influenced by the changes and transformations it experienced. Studies that focused on the process of interaction in humanenvironment relations recently emphasized that there was a link between "place" and "place attachment," and humans and places (Williams et al., 1992; Bonaiuto et al., 1999; Jorgensen \& Stedman, 2001; Williams \& Vaske, 2003; Özkan \& Yllmaz, 2019). Thus, it is necessary to address the spatial properties that allow individuals to connect with urban open places and to analyze whether these properties meet the user needs. In this direction, the concepts of open place performance and place satisfaction will be explained by focusing on the success criteria offered by urban open place. 


\section{Urban Open Place Attributes}

Canter (1977) stated that the experiences in a place are a combination of both physical and social attributes. Thus, human behavior occurs in a specific physical and social environment that meets the needs of the individual and produces emotions such as satisfaction and dissatisfaction. Within the context of the urban phenomenon, these environments are the urban open places. Within the scope of humanenvironment interaction, the studies on the environmental properties that urban open places should offer primarily focused on human needs. The development of successful urban open places is associated with meeting human needs and requirements (Whyte; 1980; Francis, 2003; Mumcu et al., 2017). Therefore, when designing urban open places, it is necessary to focus primarily on user needs. Maslow (1954), one of the pioneers in the field of human needs, categorized human needs into 6 groups: physiological, security, belonging, respectability, self-realization, and aesthetical-emotional satisfaction. Maslow's (1954) Hierarchy of Human Needs model has been interpreted differently by different researchers, allowing them to define various environmental properties. Lang (1987) categorized human needs into three groups: basic needs, cognitive needs, and aesthetic needs. Carr et al. (1992), on the other hand, categorized human needs into 5 groups as comfort, relaxation, passive engagement, active engagement, and discovery. The above-mentioned authors, who attempted to reduce human needs to urban open places, also described urban open place attributes. Whyte (2000), who argued that recognition of user requirements in urban open places was also an indicator of the success of that place, analyzed hundreds of urban open places within the scope of "Projects for Public Place" (PPS) and categorized the criteria for success in 4 groups of uses and activities, comfort and image, access and linkages, and sociability.

Researchers, who supported human-environment interaction and investigated user needs and requirements in urban open places, emphasized that the functional, social, and perceptual attributes of places should be analyzed together. Salama and Azzali (2015), in a study conducted on urban open places, emphasized that functional, social, and perceptual attributes of open places should be analyzed together. Thus, the present study analyzed the physical and social attributes provided by the place based on the user needs in urban open places (Maslow, 1954; Whyte, 1980; Francis, 2003), the attributes of successful open places (PPS, 20,00), and urban open place attributes proposed by Salama and Azzali (2015) and Shehab and Salama (2018). The post-occupancy evaluation" method was used to determine the performance of physical and social attributes provided by the place. The place of this method in the design and construction process and its later purposes will be explained in detail, and its importance in determining place performance and place satisfaction will be emphasized.

\section{Post-occupancy evaluation}

Within the context of human-environment relations, humans have expectations from their environment due to their requirements. These requirements include facilities that could help individuals to be productive in their place and workplace. To determine these facilities, it is first necessary to focus on human behavior and environmental variables (Lang, 1994). When individual encounters the environment, 
he/she assesses the environment based on his/her needs and requirements. If the environment is equipped to meet these needs and requirements, the individual develops a sense of satisfaction and occupied the environment. If the facilities provided by the environment do not adequately meet the needs of the user, that would lead to dissatisfaction and the individual occupies the environment for a short period or changes his/her environment (Özkan et al. 2015). Within the context of human-environment interactions, this process, where the facilities provided by the place is assessed to fulfill user requirements, is called the post-occupancy evaluation process (Figure 1).

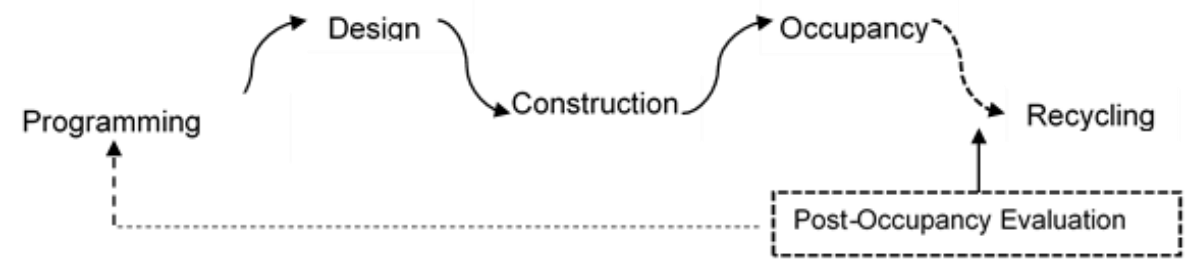

Environmental design and landscape architecture constitute an integral part of human activities. Particularly, the decrease in the number and dysfunctional state of the open places demonstrated that the focus should be on the evaluation of the users when designing these places. POE is the process of the evaluation of the place by the users after construction and occupancy for a period of time. Thus, it focuses on the users of the place and the requirements of these users and allows the assessment of user satisfaction or dissatisfaction (Preiser \& Rabinowitz, 1987; Marans \& Cooper, 2000; Preiser, 2001). The objectives of the POE are summarized below:

- To conduct a systemic analysis of spatial occupancy,

- To determine spatial performance, which is the level at which place meets the user needs and requirements,

- To develop recommendations to improve spatial performance and to provide input for the programming stage (Preiser, Rabinowitz \& White, 1988).

At this stage, it is necessary to focus on what the concept of "performance" is, how it is measured and its relationship with place satisfaction.

\section{Open place performance}

Performance concept, in which open place qualities and spatial uses are determinant, is one of the success criteria based on human-place interaction. The concept of performance, which is the level of fulfilling user requirements, could also be interpreted as measurable spatial behavior. The values that reflect user experiences, perceptions, measurements, and references are performance indicators. Thus, the concept of performance is used to describe the desired attributes of a material, component, or system in the fulfillment of user requirements (Sanoff, 1977, as cited in Özkan, 2011). It provides benefits in terms of evaluation of performance dimensions, determination and improvement of the qualities of the evaluated place. In this way, it becomes easier to design places that meet user needs and requirements at a high level and to ensure place satisfaction. As stated by Project Public Place (PPS, 2000), "Place Performance Evalution (PPE)" is a place-oriented improvement
Figure1.Post-occupancy evaluation process (Preiser and Nasar, 2008). 
approach. Creates data for the programming process in the redesign process by determining the good and bad features of the place.

Performance is the measurable view of user needs, an abstract concept that cannot be observed (Aydin \& Uysal 2009). For this reason, this research focused on the concept of "Open Place Performance". In order to evaluate the place performance, first of all, the features defining the place should be determined. In this context, Canter (1977) focused on the physical, social and perceptual features of the place, which originate from the ground theory. Salama (2018) reported that three basic elements could be used to analyze the performance of a built environment. The first included health, safety, and technical dimensions, the second included functional dimensions, and the third included psychological and social dimensions of user satisfaction. These place performance levels are an indicator of place satisfaction. In the present study, each open place attribute was analyzed as a performance indicator and the correlation between the spatial performance determined by the users and user satisfaction was tested.

\section{Place satisfaction}

Place satisfaction is described as the physical and social means that would meet the needs of individuals in a place (Stedman, 2002). The concept of satisfaction has attracted the attention of several researchers in the fields of recreation, tourism, and entertainment and was considered as the key to success in these fields (Sirgy, 2010; Ramkissoon, Smith \& Weiler, 2013a). Canter and Rees (1982) defined the concept of satisfaction as the opportunities provided by a place that help users to achieve their goals. Stedman (2002) described place satisfaction as the perceived quality of a place and stated that it reflects the physical, functional, and perceptual dimensions of the place. In studies on satisfaction, the place is initially evaluated by the users. As mentioned above, in the interaction between the individual and place, the level of satisfaction created by the functional, social, and perceptual attributes offered by the place determines the satisfaction level (Stedman, 2002; Kyle, 2004; Özkan \& Yılmaz, 2019). Thus, the question about the attributes of a location/place that would facilitate that would lead to satisfaction arises. The present study aimed to answer this question using the post-occupancy evaluation method and focused on the correlation between the functional, social, and perceptual attributes of the place and satisfaction (Figure 2).

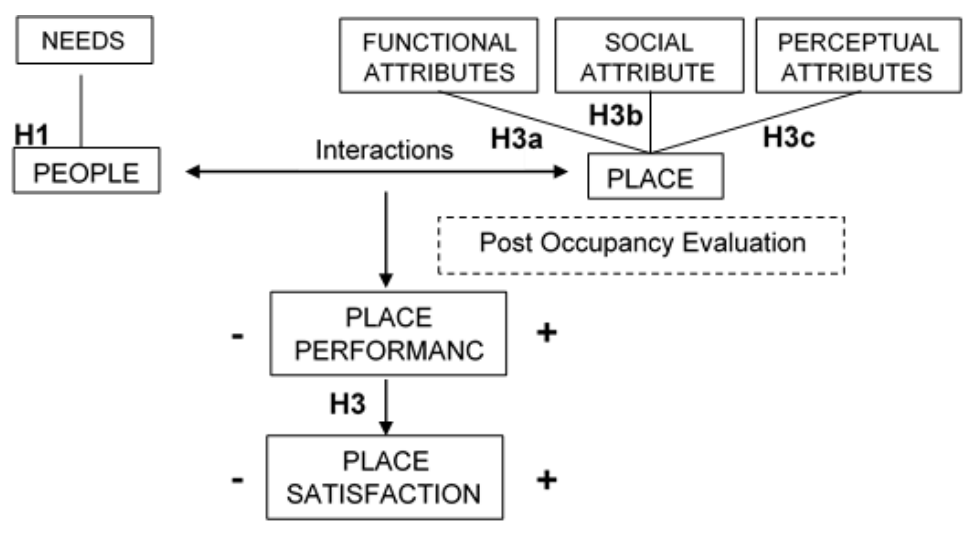


H1a. There is no significant difference between the sociodemographic variable of gender and functional, social, and perceptual attributes.

H1b. There is no significant difference between the sociodemographic variable of age and functional, social, and perceptual attributes.

H2. There is a significant difference between spatial occupancy characters and functional, social, and perceptual attributes.

H3. Overall spatial performance increases place satisfaction.

H3a. There is a positive correlation between place satisfaction and functional attributes.

$\mathrm{H} 3 \mathrm{~b}$. There is a positive correlation between place satisfaction and social attributes.

H3c. There is a positive correlation between place satisfaction and perceptual attributes.

\section{MATERIAL AND METHOD}

\section{Study Area}

The present study aimed to determine the effects of functional, social, and perceptual attributes of urban open places on place performance and place satisfaction via post-occupancy evaluation. The study was conducted in the Arsin district of Trabzon province, located in the Eastern Black Sea region in Turkey (Figure 3).

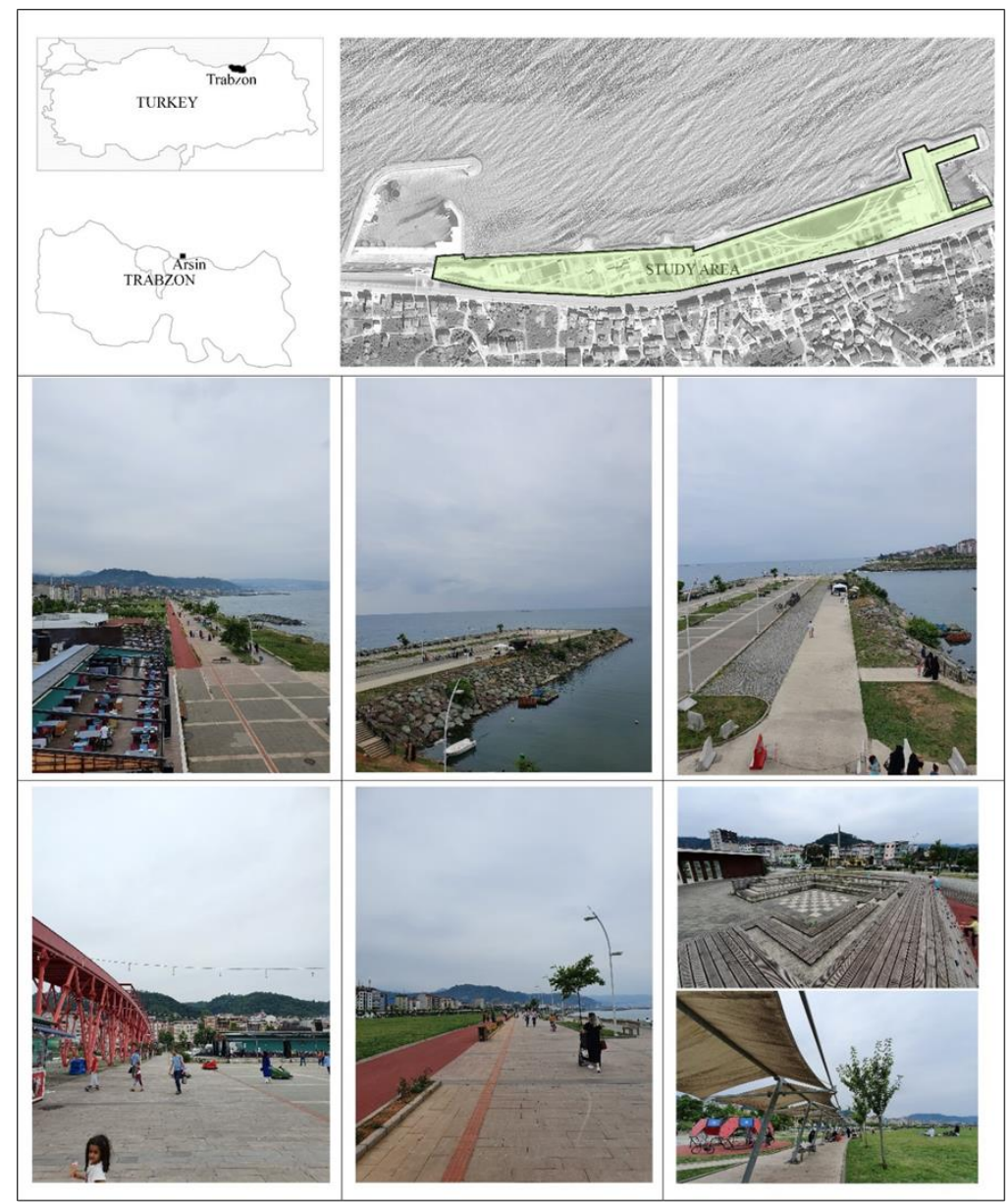

Figure 3. Location of the study area (Source: Authors) 
Coastal recreation areas were built due to the increase in construction in Trabzon province and its surrounding areas and the resulting decrease in urban open places. The study area, which was designed within the context of urban transformation projects and completed in 2015, is very important in extending the potential of constantly decreasing green areas and the relationships between people and sea coast (Acar, 2015). Furthermore, Arsin Coastal Park-ACP was selected as the study area due to its diverse functional, social, and perceptual attributes, occupancy by all urban residents, and its focal location (Figure 4).

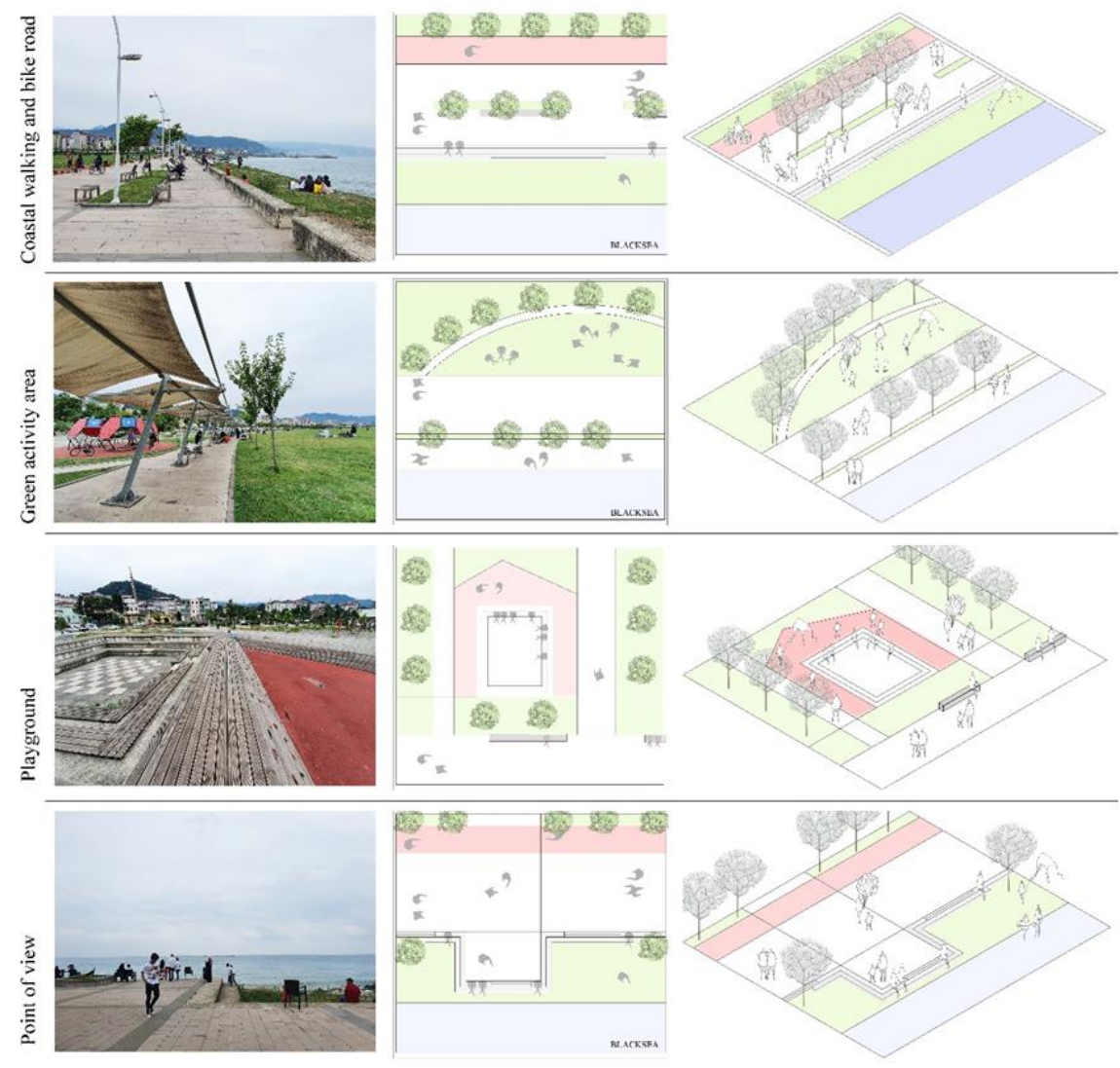

Figure 4. Variety of activities in the study area

\section{Survey and Participants}

It is expected that the spatial performance and the place satisfaction would increase as the level of fulfillment of user needs by the facilities provided by the place increases. Thus, the general framework of the present study included the determination of spatial performance and place satisfaction with the evaluation of the spatial functional, social, and perceptual attributes by the users (post-occupancy evaluation). The research design included the following main stages:

- Evaluation of the functional, social, and perceptual attributes of the selected coastal place by the users.

- Determination of the spatial performance level.

- Determination of the place satisfaction level. 
- Determination of the correlations and causality between the above-mentioned factors by analyzing all collected data.

Based on the above-mentioned objectives, survey questions were constructed in two categories: functional, social, and perceptual attributes of the place, and place satisfaction. Each item was scored on a 5-point Likert-type scale ( 1 = strongly disagree, 5 = strongly agree). Subjects included randomly selected users of the Arsin coastal park. The questionnaires were applied to 243 individuals on weekdays and weekends. Data were entered, edited, and analyzed using the Statistical Package for Social Sciences (SPSS) Version 24.0.

\section{Survey Instruments Used to Determine Functional, Social and Perceptual Attributes of the Coastal Place (Coastal Place Performance Evaluation)}

As an area of interaction between individuals and the environment, coasts constitute an important part of the urban environment with their diverse functional, social, and perceptual attributes. People are attracted by these places based on the success of these functional, social, and perceptual attributes offered by coastal areas. This success is measured with the spatial performance which is the level that place fulfills the needs and requirements of the users.

In the first stage of the study, the functional, social, and perceptual attributes of the coastal place were analyzed and the answer to the question "which attributes are required to create places with a high-level performance" was determined. Thus, in the present study, user needs in urban open places (Maslow, 1954; Whyte, 1980; Francis, 2003), the attributes that successful open places should possess (PPS, 2000), the functional, social and perceptual analysis reported by Salama and Azzali (2015), and physical and social attributes of the place reported by Özkan and Yllmaz (2019) were used (Table 1). The indicators presented in Table 1 were analyzed with the post-occupancy evaluation method that includes the user evaluations to determine spatial performance.

Table 1. The categorization of urban open place attributes (developed based on Maslow, 1954; Whyte,1980; Francis; 2003; PPS, 2000; Salama and Azzali, 2015; Özkan \& Yllmaz, 2019).

\begin{tabular}{|l|l|l|}
\hline \multicolumn{3}{|c|}{ SETTING ( OPEN PLACE) } \\
\hline Functional attributes & Social attributes & Perceptual attributes \\
\hline Diversity of use & Promoting effective user & Safety and security \\
\hline Environmental & Social inclusivity & Personal place and privacy \\
\hline Appropriateness of use & Diverse social group & Comfort and relaxation \\
\hline Accessibility & Diverse social activities & Memorable landscape \\
\hline Visibility and & Interaction social group & Spatial experience \\
\hline Clarity of edges laccessibility & Reflecting local identity \\
\hline Quality of landscape & Common uses & Attractiveness \\
\hline Adaptability formal & Legibility \\
\hline Opportunity & Informal and for faily & \\
\hline & Security (social) & Popularity of place \\
\hline & Availability for d \\
\hline
\end{tabular}




\section{Survey Instruments for Place Satisfaction}

The final stage of the research method was the determination of the place satisfaction levels of Arsin coastal area users. Stedman (2002) described place satisfaction as the perceived quality of a location and the physical and social attributes of a place that fulfills the user needs. Within the context of open places, the discussion on correlations between place, place attachment, and place satisfaction continues. However, there are no studies in the literature on the correlation between open place performance evaluation and place satisfaction. In this stage of the research methodology, the main objective was to determine the satisfaction with the place. Thus, a 3-item scale developed by Yuksel et al. (2010) and tested for validity and reliability was used.

A 5-point Likert-type scale ( 1 = strongly disagree, 5 = strongly agree) was utilized in both the main stages of the study. Data were entered, edited, and analyzed with SPSS Version 24 software. Descriptive statistics were used to determine individual and group means, percentages, and frequencies. To explain the place attributes and sub-dimensions, initially, $\mathrm{KMO}$ analyzes that demonstrate the fitness of the factor analysis were conducted. A principal component factor analysis that included varimax rotation with Kaizer normalization was run to explore the underlying environmental attribute dimensions. An eigenvalue of 1.00 or more was used to identify potential factors. Cronbach's reliability test was conducted on environmental attributes. Finally, regression analyzes were applied to test the correlation between place satisfaction and each spatial performance dimension.

\section{RESULTS}

\section{Sociodemographic and Visitation Characteristics}

Two hundred and forty-three Arsin Coastal Park users were included in the study. A total of $45.5 \%$ of the participants were female and $54.5 \%$ male and the mean participant age was $36.5(\mathrm{SD}=16.08$, age range: 18 70). The study was conducted in ACP on one weekday and one weekend day in May 2019. Occupancy frequency analysis demonstrated that the users mostly visited the place on weekends $(38.5 \%, \mathrm{SD}=0.96$, range: 1 5). Finally, occupancy duration analysis demonstrated that the users mostly spent 3-4 hours $(32.4 \%, \mathrm{SD}=1.05$, range $=1-5)$ in the park.

\subsection{Coastal Place Performance Evaluation}

In the study, factor analysis was conducted on 29 statements developed to assess the functional, social, and perceptual performances of the open places in ACP, and after several analyzes, the scales were finalized after various reliability tests that demonstrated the fitness in factor analysis. The principal components analysis with varimax rotation was conducted in 6 replicates. Finally, the 29 -item open place performance analysis scale was reduced to 22 items that included 3 factors (Table 2). These factors explained $65.906 \%$ of the total variance. Kaiser Meyer Olkin (KMO) value 
was determined as 0.906 and the Bartlett sphericity test was conducted $(\chi 2: 4703.180$, df: $236, p<0.001)$ to determine the fitness of the scale for factor analysis.

As a result of the exploratory factor analysis, the first factor was determined as "functional performance." This factor alone explained $43.367 \%$ of the total variance and included 8 items. The second factor was determined as "social performance." This factor explained 15.654\% of the total variance and included 7 items. The third and final factor was determined as "perceptual performance." This factor explained $6.885 \%$ of the total variance and included 7 items. The analysis results revealed a three-factor, 22 -item scale, and these three factors explained $65.906 \%$ of the total variance, and the reliability coefficient was determined as $\alpha: 0.937$.

Table 2. Principle component analysis of coastal place performance items

\begin{tabular}{|c|c|c|c|c|c|}
\hline \multirow[t]{2}{*}{ Construct / Indicators / Variables } & \multicolumn{4}{|c|}{$\begin{array}{l}\text { Exploratory factor analysis } \\
\text { (Varimax rotation) })^{\mathrm{a}}\end{array}$} & \multirow[b]{2}{*}{ S.D.c } \\
\hline & 1 & 2 & 3 & Mean ${ }^{b}$ & \\
\hline Functional performance & & & & 3.44 & 1.312 \\
\hline $\begin{array}{l}\text { 3.This space allows various activities } \\
\text { to take place }\end{array}$ & 0.810 & 0.173 & 0.235 & 3.49 & 1.126 \\
\hline $\begin{array}{l}\text { 4. Suitable for architectural and } \\
\text { landscaping elements }\end{array}$ & 0.776 & 0.071 & 0.371 & 3.51 & 1.137 \\
\hline $\begin{array}{l}\text { 1. Reinforcement elements are } \\
\text { comfortable and useful in this area }\end{array}$ & 0.753 & 0.150 & 0.380 & 3.48 & 1.126 \\
\hline 2.I can easily access this area & 0.730 & 0.162 & 0.370 & 3.44 & 1.178 \\
\hline $\begin{array}{l}\text { 7.The form of the field is suitable for } \\
\text { current uses }\end{array}$ & 0.729 & 0.188 & 0.293 & 3.35 & 1.063 \\
\hline $\begin{array}{l}\text { 8.This area contains iconic elements } \\
\text { that make it visible from a distance }\end{array}$ & 0.690 & 0.288 & 0.315 & 3.51 & 1.042 \\
\hline $\begin{array}{l}\text { 6.This area has obvious boundaries / } \\
\text { edges }\end{array}$ & 0.654 & 0.151 & 0.331 & 3.46 & 1.110 \\
\hline $\begin{array}{l}\text { 5. Guidance elements are sufficient in } \\
\text { this area. }\end{array}$ & 0.642 & 0.308 & 0.071 & 3.30 & 1.152 \\
\hline Social performance & & & & 3.03 & 0.895 \\
\hline $\begin{array}{l}\text { 11. The space supports interaction } \\
\text { and activities between people. }\end{array}$ & 0.193 & 0.941 & 0.062 & 2.99 & 0.904 \\
\hline $\begin{array}{l}\text { 13.The area allows the use of many } \\
\text { different social groups. }\end{array}$ & 0.185 & 0.932 & 0.088 & 2.96 & 0.885 \\
\hline $\begin{array}{l}\text { 9. This area allows for daily } \\
\text { encounters. }\end{array}$ & 0.158 & 0.903 & 0.033 & 2.99 & 0.870 \\
\hline $\begin{array}{l}\text { 15. I can make eye contact with other } \\
\text { people in this area. }\end{array}$ & 0.102 & 0.871 & 0.016 & 3.14 & .965 \\
\hline $\begin{array}{l}\text { 10. Various social activities take place } \\
\text { in this area. }\end{array}$ & 0.090 & 0.605 & 0.235 & 2.93 & 1.056 \\
\hline $\begin{array}{l}\text { 14. This area promotes interaction } \\
\text { between different social groups. }\end{array}$ & 0.146 & 0.589 & 0.194 & 2.89 & .862 \\
\hline $\begin{array}{l}\text { 12. This space allows me to meet } \\
\text { different people. }\end{array}$ & 0.224 & 0.492 & 0.102 & 3.35 & 1.181 \\
\hline Perceptual performance & & & & 3.36 & 1.178 \\
\hline $\begin{array}{l}\text { 19. It gives the users a sense of } \\
\text { security and security. }\end{array}$ & 0.295 & 0.063 & 0.818 & 3.35 & 1.181 \\
\hline $\begin{array}{l}\text { 17. The physical design of the area } \\
\text { supports the feeling of comfort and } \\
\text { relaxation. }\end{array}$ & 0.265 & 0.029 & 0.802 & 3.51 & 1.062 \\
\hline $\begin{array}{l}20 \text {. This area is fairly easy to navigate } \\
\text { and navigate. }\end{array}$ & 0.335 & 0.027 & 0.785 & 3.13 & 1.094 \\
\hline
\end{tabular}


Analysis of The Effects of Open Place Performance on Users' Satisfaction Using Post-Occupancy Evaluation

\begin{tabular}{|l|l|l|l|l|l|}
\hline \hline $\begin{array}{l}\text { 16. This venue is recognized and used } \\
\text { by local residents. }\end{array}$ & 0.214 & 0.129 & 0.784 & 3.23 & 1.038 \\
\hline $\begin{array}{l}\text { 21. Spatial experience in this area is } \\
\text { highly interesting. }\end{array}$ & 0.293 & 0.128 & 0.747 & 3.31 & 1.110 \\
\hline $\begin{array}{l}\text { 22. The architectural and landscape } \\
\text { character of this place reflects the } \\
\text { identity of Trabzon. }\end{array}$ & 0.216 & 0.292 & 0.636 & 3.49 & 1.126 \\
\hline $\begin{array}{l}\text { 18. This area constitutes an attractive } \\
\text { area for those living in the region. }\end{array}$ & 0.317 & 0.235 & 0.617 & 3.50 & 1.137 \\
\hline Initial eigenvalues & 9.541 & 3.444 & 1.515 & & \\
\hline \% of variance & 43.367 & 15.654 & 6.885 & & \\
\hline Reliability (Cronbach alpha) & 0.922 & 0.896 & 0.910 & & \\
\hline Mean & 27.53 & 20.87 & 23.14 & & \\
\hline Variance & 51.589 & 25.632 & 39.410 & & \\
\hline Std. Deviation & 7.183 & 5.063 & 6.278 & & \\
\hline Kaiser-Meyer-Olkin (KM0): 0.906. Bartlett's Test p<0.001 & & & \\
\hline
\end{tabular}

\section{Place Satisfaction}

The mean scores and standard deviations for the statements that aimed to assess the satisfaction levels of ACP users were determined. Exploratory factor analysis (EFA) was conducted on the statements that aimed to determine the place satisfaction and it was found that 3 items were included in a single factor that explained $77.049 \%$ of the total variance (Table 3). The mean spatial satisfaction level was 3.18.

Table 3. Frequency distribution for place satisfaction items and exploratory factor analysis

\begin{tabular}{|l|c|c|c|}
\hline Construct / Indicators / Variables & \multicolumn{3}{|c|}{$\begin{array}{c}\text { Exploratory factor } \\
\text { analysis } \\
\text { (Varimax rotation) }\end{array}$} \\
\hline Coastal Place Satisfaction & 1 & Mean $^{\mathrm{b}}$ & S.D. $^{\mathrm{c}}$ \\
\hline I believe I did the right thing when I chose to visit this & 0.955 & 3.05 & 0.992 \\
\hline Overall, I am satisfied with my decision to visit this & 0.933 & 3.19 & 1.044 \\
\hline I am happy about my decision to visit this ACP & 0.728 & 3.30 & 1.115 \\
\hline Initial eigenvalues & 2.311 & & \\
\hline$\%$ of variance & 77.049 & & \\
\hline Reliability (Cronbach alpha) & 0.848 & & \\
\hline Mean & 3.18 & & \\
\hline Varience & 0.849 & & \\
\hline Std. Deviation & 0.9211 & & \\
\hline Kaiser-Meyer-Olkin (KMO): 0.801. Bartlett's Test & & & \\
\hline $\begin{array}{l}\text { Note. Items coded on 5-point scales ranging from strongly disagree (1) to strongly } \\
\text { agree (5). }\end{array}$ & & \\
\hline
\end{tabular}

\section{Relationships Between Place Performance, Place Satisfaction and Socio-demographics}

Based on the ACP user evaluation findings, t-test and one-way analysis of variance (ANOVA) were used to determine whether spatial performance and place satisfaction levels differed based on gender, age, occupancy frequency, and duration (Table 4). Analysis results demonstrated that functional, social, and perceptual performance levels did not differ based on gender (H1a was accepted). Based on the age variable, functional and social performance perception of the place differed (H1b was rejected) 
and it was determined that there was no difference between perceptual performance dimensions ( $\mathrm{H} 1 \mathrm{~b}$ was accepted). There were statistically significant differences between the overall performances of spatial occupancy frequency and duration, and place satisfaction (H2 was accepted).

Table 4. Relationship between place performance, place satisfaction and sociodemographics

\begin{tabular}{|c|c|c|c|c|c|c|c|c|c|c|}
\hline \multirow{3}{*}{ Factors } & & & \multicolumn{8}{|c|}{ Socio-demographic and visitation characteristics } \\
\hline & & & \multicolumn{2}{|c|}{ Sex } & \multicolumn{2}{|c|}{ Age } & \multicolumn{2}{|c|}{$\begin{array}{c}\text { Frequency } \\
\text { of Use }\end{array}$} & \multicolumn{2}{|c|}{$\begin{array}{l}\text { Length of } \\
\text { Use }\end{array}$} \\
\hline & $\begin{array}{c}\text { Mea } \\
\mathrm{n}\end{array}$ & SD & $\mathrm{T}$ & Sig. & $\mathrm{F}$ & Sig. & $\mathrm{F}$ & Sig. & $\mathrm{F}$ & Sig. \\
\hline $\begin{array}{l}\text { Functiona } \\
\text { l }\end{array}$ & 2.98 & $\begin{array}{l}0.72 \\
3\end{array}$ & $\begin{array}{l}1.08 \\
6\end{array}$ & $\begin{array}{l}0.88 \\
6\end{array}$ & $\begin{array}{l}3.59 \\
8\end{array}$ & $\begin{array}{l}0.00 \\
7\end{array}$ & $\begin{array}{l}4.37 \\
7\end{array}$ & $\begin{array}{l}0.00 \\
2\end{array}$ & $\begin{array}{l}2.00 \\
5\end{array}$ & $\begin{array}{l}0.00 \\
0\end{array}$ \\
\hline Social & 3.44 & $\begin{array}{l}0.89 \\
7\end{array}$ & $\begin{array}{l}1.33 \\
5\end{array}$ & $\begin{array}{l}0.24 \\
9\end{array}$ & $\begin{array}{l}2.73 \\
7\end{array}$ & $\begin{array}{l}0.03 \\
0\end{array}$ & $\begin{array}{l}8.25 \\
3\end{array}$ & $\begin{array}{l}0.00 \\
0\end{array}$ & $\begin{array}{l}11.7 \\
87\end{array}$ & $\begin{array}{l}0.00 \\
0\end{array}$ \\
\hline $\begin{array}{l}\text { Perceptua } \\
\text { l }\end{array}$ & 3.30 & $\begin{array}{l}0.89 \\
6\end{array}$ & $\begin{array}{l}0.93 \\
7\end{array}$ & $\begin{array}{l}0.93 \\
7\end{array}$ & $\begin{array}{l}1.10 \\
7\end{array}$ & $\begin{array}{l}0.35 \\
4\end{array}$ & $\begin{array}{l}2.59 \\
5\end{array}$ & $\begin{array}{l}0.03 \\
7\end{array}$ & $\begin{array}{l}18.9 \\
59\end{array}$ & $\begin{array}{l}0.00 \\
0\end{array}$ \\
\hline $\begin{array}{l}\text { Place } \\
\text { satisfactio } \\
\text { n }\end{array}$ & 3.18 & $\begin{array}{l}0.92 \\
11\end{array}$ & $\begin{array}{l}0.82 \\
3\end{array}$ & $\begin{array}{l}0.51 \\
2\end{array}$ & $\begin{array}{l}5.01 \\
1\end{array}$ & $\begin{array}{l}0.00 \\
1\end{array}$ & $\begin{array}{l}2.19 \\
2\end{array}$ & $\begin{array}{l}0.00 \\
0\end{array}$ & $\begin{array}{l}6.00 \\
2\end{array}$ & $\begin{array}{l}0.00 \\
0\end{array}$ \\
\hline $\begin{array}{l}\text { Overall } \\
\text { Performa } \\
\text { nce }\end{array}$ & 3.07 & $\begin{array}{l}1.04 \\
4\end{array}$ & $\begin{array}{l}0.41 \\
9\end{array}$ & $\begin{array}{l}0.51 \\
8\end{array}$ & $\begin{array}{l}1.28 \\
7\end{array}$ & $\begin{array}{l}0.27 \\
6\end{array}$ & $\begin{array}{l}4.02 \\
1\end{array}$ & $\begin{array}{l}0.00 \\
4\end{array}$ & $\begin{array}{l}3.12 \\
0\end{array}$ & $\begin{array}{l}0.01 \\
6\end{array}$ \\
\hline
\end{tabular}

\section{Relationships Between Place Satisfaction and Place Performance} Dimensions

Correlation analysis was conducted to determine the correlations between socio-demographic characteristics, spatial performance, and place satisfaction assessments of ACP users (Table 5). Correlation analysis findings demonstrated that there were no significant correlations between spatial satisfaction and performance dimensions and general performance and age and gender dimensions. There was a significant and positive correlation between overall performance and place satisfaction $(r=0.540 * * ; p=0.000)$. The correlations between functional performance, social performance, and perceptual performance sub-dimensions of spatial performance were tested and positive and significant correlations were determined among these variables. The correlations between these variables and place satisfaction were as follows: functional performance $\left(\mathrm{r}=0.707^{* *} ; \mathrm{p}=\right.$ 0.000) (H3a was accepted), social performance $\left(r=0.565^{* *}, r=0.000\right)$ (H3b was accepted), perceptual performance $\left(r=0.384^{* *} ; \mathrm{p}=0.000\right)($ H3c was accepted). 
Analysis of The Effects of Open Place Performance on Users' Satisfaction Using Post-Occupancy Evaluation

Table 5. Correlation analysis table

\begin{tabular}{|c|c|c|c|c|c|c|c|c|c|}
\hline & G & A & FU & LU & FP & SP & PP & PS & $\begin{array}{l}0 \\
P\end{array}$ \\
\hline G & 1 & & & & & & & & \\
\hline A & 0.072 & 1 & & & & & & & \\
\hline $\mathrm{FU}$ & 0.021 & -0.004 & 1 & & & & & & \\
\hline $\mathrm{LU}$ & 0.055 & 0.046 & $0.405^{* *}$ & 1 & & & & & \\
\hline FP & 0.075 & -0.050 & $0.169^{* *}$ & $0.178^{* *}$ & 1 & & & & \\
\hline SP & $\begin{array}{c}- \\
0.018 \\
\end{array}$ & -0.053 & $0.265^{* *}$ & $0.402^{* *}$ & $0.446^{* *}$ & 1 & & & \\
\hline PP & 0.026 & 0.062 & $0.155^{*}$ & $0.491^{* *}$ & $0.334^{* *}$ & $\begin{array}{c}0.682^{*} \\
*\end{array}$ & 1 & & \\
\hline PS & 0.041 & -0.089 & $0.354^{* *}$ & $0.364^{* *}$ & $0.707^{* *}$ & $\underset{*}{0.565^{*}}$ & $\underset{* *}{0.384}$ & 1 & \\
\hline $\mathrm{OP}$ & 0.003 & -0.009 & $0.176^{* *}$ & $0.216^{* *}$ & $0.535^{* *}$ & $\begin{array}{c}0.456^{*} \\
*\end{array}$ & $\begin{array}{c}0.270 \\
* *\end{array}$ & $\begin{array}{c}0.5 \\
40^{* *}\end{array}$ & 1 \\
\hline
\end{tabular}

G: Gender, A: Age, FU: Frequency of Use, LU: Length of Use, FP: Functional Performance, SP: Social Performance, PP: Perceptual Performance, PS: Place Satisfaction, OP: Overall Performance

Regression analysis was conducted to determine the effects of spatial performance and its sub-dimensions on place satisfaction (Table 6). The regression analysis results revealed that $32.6 \%$ of spatial satisfaction could be predicted by functional performance, $12.4 \%$ by social performance, and $5.1 \%$ by perceptual performance. The overall performance level could predict $49.6 \%$ of place satisfaction (H3 was accepted).

Table 6. Regression analysis using place performance factors to predict place satisfaction

\begin{tabular}{|c|c|c|c|c|c|}
\hline Model & B & Std. Hata & $\beta$ (Beta) & $\mathrm{t}$ & $\mathrm{p}$ \\
\hline Constant & 3.182 & 0.049 & & 65.609 & 0.000 \\
\hline Functional Performance & 0.528 & 0.049 & 0.574 & 10.871 & 0.000 \\
\hline \multicolumn{6}{|c|}{$R=0.574 ; R^{2}=0.329 ;$ Adj. $R^{2}=0.326 ;$ Model $F_{(1-241)}=118.180 ; p<0.01$} \\
\hline Constant & 3.182 & 0.055 & & 57.536 & 0.000 \\
\hline Social Performance & 0.329 & 0.055 & 0.357 & 5.935 & 0.000 \\
\hline \multicolumn{6}{|c|}{$R=0.357 ; R^{2}=0.128 ;$ Adj. $R^{2}=0.124 ;$ Model $F_{(1-241)}=35.222 ; p<0.01$} \\
\hline Constant & 3.182 & 0.058 & & 55.287 & 0.000 \\
\hline Perceptual Performance & 0.216 & 0.058 & 0.235 & 3.748 & 0.000 \\
\hline \multicolumn{6}{|c|}{$R=0.235 ; R^{2}=0.055 ;$ Adj. $R^{2}=0.051 ;$ Model $F_{(1-241)}=14.047 ; p<0.01$} \\
\hline Constant & 0.692 & 0.167 & & 4.153 & 0.000 \\
\hline Overall Performance & 0.724 & 0.047 & 0.706 & 15.454 & 0.000 \\
\hline
\end{tabular}

Regression analysis was conducted again to determine the prediction level of all variables on place satisfaction (Table 7). Regression analysis results demonstrated that it was not possible to add the occupation duration variable, which correlated with place satisfaction, to the model. In Table 6, it could be observed that all spatial performance factors predicted place satisfaction. The figures gradually increased and at the 
last step, the R2 value was calculated as 0.537 . The analysis was consistent with the linear model $(\mathrm{F}(4-237)=71.002 ; \mathrm{p}=0.000)$ and autocorrelation was not observed. Thus, it was demonstrated that spatial performance factors had significant positive effects on place satisfaction.

Table 7. Regression analysis using all independent variables to predict place satisfaction

\begin{tabular}{|l|l|l|l|l|l|l|}
\hline \multicolumn{2}{|l|}{ Model } & B & Std. & $\beta($ Beta $)$ & $\mathrm{t}$ & $\mathrm{p}$ \\
\hline \multirow{3}{*}{4} & Constant & 2.724 & 0.121 & & 22.593 & 0.000 \\
\cline { 2 - 7 } & Functional Performance & 0.491 & 0.042 & 0.531 & 11.172 & 0.000 \\
\cline { 2 - 7 } & Social Performance & 0.324 & 0.040 & 0.351 & 8.013 & 0.000 \\
\cline { 2 - 7 } & Perceptual Performance & 0.196 & 0.041 & 0.213 & 4.815 & 0.000 \\
\hline \multicolumn{2}{|l|}{ Frequency of Use } & 0.174 & 0.043 & 0.183 & 4.005 & 0.000 \\
\hline$R=0.738 ; R^{2}=0.545 ;$ Adj. $R^{2}=0.537 ;$ Model $F(4-237)=71.002 ; p<0.01$ \\
\hline
\end{tabular}

In conclusion, the study demonstrated the findings on the analysis of socio-demographic characteristics, spatial visit character, open place performance criteria, place satisfaction, and all of these attributes. All study findings confirmed all hypotheses except the $H 2 b$ hypothesis.

\section{DISCUSSION AND IMPLICATIONS}

This study was examined based on place-oriented performance evaluation and it was seen that the open place performance was explained in 3 dimensions as functional, social and perceptual. Analysis of the study findings demonstrated that functional, social, and perceptual performance criteria did not differ based on the gender variable. It was found that age socio-demographic variable differed based on functional and social performance dimensions, but not based on the perceptual performance dimension. It could be suggested that the difference between functional and social performance dimensions based on age was due to the differences between the physical and social needs of the age groups. A significant difference was determined between functional, social, and perceptual performance levels based on occupancy frequency and duration. This finding was consistent with the previous study findings that the occupancy frequency and duration in a place correlated with the level that the place fulfilled user requirements (Whyte, 1980; Ali \& Nawawi, 2006; Insch \& Florek, 2008; Ramkissoon, 2013b).

Analysis of the study findings based on the attributes of the place revealed that the coastal place performance evaluation included a 3dimensional structure (functional, social, and perceptual). This result supports Salama et al (2017)'s open place classification in Glasgow city center. The highest impact was observed with functional performance and the lowest impact was observed with the social performance dimension. Analysis of the spatial organization in ACP demonstrated that various activities could be conducted in that place. Therefore, the higher 
impact of the functional performance dimension was an expected outcome. The design character of the field was readable and distinguishable since its construction was linear. However, the low level of spatial social performance could be explained by the disadvantages of this linear design approach. Analysis of the locations of the seating and activity areas where users could interact (Figure 2) revealed that the socio-fugal approach was predominant. This approach prevents interuser communication and eye contact. However, it was observed that the functional, social, and perceptual performances of the park were at medium and high levels. Today, the functionality of a place is very important in human-environment interaction. People prefer places where they can fulfill their specific needs and behaviors to fulfill these needs (Mazumdar \& Mazumdar; Özkan \& Yılmaz, 2019). Thus, place is experienced, leading to occupancy diversity and socialization. Gehl (2011) emphasized the importance of the functional attributes of the place by stating that humans and human activities attract other individuals to that place. Similarly, Madureira et al. (2018), who studied the preference levels in urban open places in 3 Portuguese cities, reported that structural and functional diversity positively affected the preference levels in parks. The fact that especially the diversity of parentchild activities in the ACP park was higher when compared to other parks in the area was also a determinant of the functional performance level. Analysis of the high scored statements in the functional performance dimension demonstrated that the statements "architectural and landscape elements are functional" (Item 4) and "the area included iconic elements that were visible from a distance" (Item 8) exhibited the highest score with a mean score of 3.51. This could be explained by the presence of open green areas and the diversity of activity areas such as children's playgrounds, watching the sea, fishing, sitting, resting, walking, and jogging. Furthermore, the construction of the red bridge as an iconic spatial element made the area perceptible and attracted people. The statement with the highest score in the social performance dimension was "the area allows me to meet different people" (Item 12) with a mean score of 3.35. In the perceptual performance dimension, the statement "the physical design of the place supports the feelings of comfort and relaxation" (Item 17) had the highest mean score of 3.51. The linear spatial design and the presence of open green areas led to a clear and legible place. Furthermore, avoiding elements that could prevent visual communication and affect the user's sense of safety in planting design could be associated with high perceptual performance.

Analysis of the spatial satisfaction in ACP revealed that the satisfaction level was moderate (3.18). To determine the place satisfaction level, initially, the post-occupancy evaluation process, which is the evaluation of the place by the users, was conducted. The satisfaction level, which was described as the result of the comparison between the expectations and real experiences of the users, is an important indicator in the evaluation of the activity areas in urban open places (Kyle et al., 2004; Insch, A., \& 
Florek, 2008; Ramkissoon et al. 2013b, Özkan et al., 2015). The present study aimed to measure the place satisfaction with spatial performance evaluation. The study findings demonstrated that overall spatial performance positively correlated with place satisfaction ( $r=0.540 * *$; $=0.000$ ) and predicted $49.6 \%$ of place satisfaction. Thus, overall spatial performance would alone explain almost half of the satisfaction. Functional performance (32.6\%), social performance (12.4\%), and perceptual performance (5.1\%) had a significant and positive impact on satisfaction.

Analysis of the effects of all variables on place satisfaction demonstrated that the variables included in the model were functional, social, perceptual performance dimensions, and occupancy frequency (54.5\%). Age, gender, and occupancy duration were not included in the model. Previous studies reported that socio-demographic factors affected place satisfaction. Lee et al. (2017) reported that there was a positive correlation between age and satisfaction. In the present study, the age variable had no significant and positive effect on satisfaction. Grogan Kaylor et al. (2006) and Lovejoy et al. (2010) reported that the age variable had no significant effect on satisfaction. The present study findings were consistent with the results of these studies in the literature. On the other hand, several studies reported that environmental character positively affected satisfaction (Amerigo \& Aragones, 1997; Howley, Scott \& Redmond, 2009; Kweon et al.2010; Özkan et al .; 2015; Lee et al., 2017). However, there are only a few studies in the literature that explained place satisfaction with spatial performance dimensions. The present study differed from previous studies by describing the role of environmental performance dimensions in a coastal open place in increasing place satisfaction.

\section{CONCLUSION AND RECOMMENDATIONS}

The present study focused on the analysis of functional, social, and perceptual attributes of the place with the post-occupancy evaluation (POE) method and aimed to investigate the effects of these attributes on place satisfaction. Thus, the study area was selected since it possessed various physical and social facilities, served a wide variety of users, was easily accessible coastal open place, and one of the large-scale transformation projects constructed in recent years.

One of the important contributions of this research is the evaluation of open place features within the scope of performance criteria and to investigate their effects on place satisfaction.There are studies in the literature that evaluated urban open place satisfaction. However, there are no studies that investigated the effects of open place performance criteria on place satisfaction using the post-occupancy evaluation (POE) method.

One of the most important properties of habitable and highly preferred urban environments is the facilities that place provides to serve all urban 
residents and that fulfill their needs and requirements. In this context, it is very important to investigate the environmental properties of the projects conducted with a focus on tourism and recreation and satisfy the user needs. The present study focused on the functional, social, and perceptual dimensions of environmental properties. Thus, considering the diversity of environmental properties, it could not be claimed that the present study methodology and findings revealed all environmental dimensions that affect satisfaction. In addition, this research, despite the variety of users it contains, still contains a local use. The research area can be diversified to evaluate the relationship between use of place and satisfaction in different cities or regions. These should be stated as the limitations of the research. Despite these limitations of the research, however, given that the widely studied spatial performance dimensions were investigated in public buildings, the present study, which was conducted in an urban open place, presented different findings. Factors that contribute to satisfaction with environmental properties should be taken into consideration, especially in the relationship between humans and the environment. These findings could serve as a guideline for urban administrators in improving urban open place satisfaction.

\section{CONFLICT OF INTEREST}

There is no conflict of interest within the scope of the study.

\section{FINANCIAL DISCLOSURE}

The authors declared that this study has received no financial support.

\section{ETHICS COMMITTEE APPROVAL}

Ethics committee approval was not required for this article.

\section{LEGAL PUBLIC/PRIVATE PERMISSIONS}

In this research, the necessary permissions were obtained from the relevant participants (individuals, institutions and organizations) during the survey, in-depth interview, focus group interview, observation or experiment.

\section{REFERENCES}

Acar, C. (2015). Kent parkları olarak kıy dolgu alanlarının değerlendirilmesi; Arsin sahil yolu dolgu alanı çevre ve peyzaj tasarım projesi, Plant Peyzaj ve Süs Bitkiciliği Dergisi, 38-47.

Ali, S. M. \& Nawawi, A. H. (2006). Factors that influence users' satisfaction on urban park, Built Environment Journal, 3(2), 42-138.

Amérigo, M. \& Aragones, J. I. (1997). A theoretical and methodological approach to the study of residential satisfaction, Journal of environmental psychology, 17(1), 47-57. 
Aydın, D. \& Uysal, M. (2009). Mimari program verilerinin mekân performansının değerlendirilmesi yoluyla belirlenmesi (Eğitim Fakültesi Örneği), Erciyes Üniversitesi Fen Bilimleri Enstitüsü Dergisi, 25(1-2), 1-23.

Bonaiuto, M., Aiello, A., Perugini, M., Bonnes, M., \& Ercolani, A. P. (1999). Multidimensional perception of residential environment quality and neighbourhood attachment in the urban environment, Journal of environmental psychology, 19(4), 331-352.

Canter, D. (1977). The psychology of place (London).

Canter, D., \& Rees, K. (1982). A multivariate model of housing satisfaction, Applied Psychology, 31(2), 185-207.

Carr, S., Francis, M., Rivlin, L. G. \& Stone, A. M. (1992). Needs in public place. na.

Francis, M. (2003). Urban open place: Designing for user needs. Island Press.

Gehl, J. (2011). Life between buildings: using public place. Island press.

Grogan-Kaylor, A., Woolley, M., Mowbray, C., Reischl, T. M., Gilster, M., Karb, R. \& Alaimo, K. (2006). Predictors of neighborhood satisfaction, Journal of Community Practice, 14(4), 27-50.

Howley, P. Scott, M. \& Redmond, D. (2009). Sustainability versus liveability: an investigation of neighbourhood satisfaction, Journal of Environmental Planning and Management, 52(t6), 847-864.

Insch, A. \& Florek, M. (2008). A great place to live, work and play: Conceptualising place satisfaction in the case of a city's residents, Journal of Place Management and Development, 1(2), 138-149.

Jorgensen, B. S. \& Stedman, R. C. (2001). Sense of place as an attitude: Lakeshore owners attitudes toward their properties. Journal of Environmental Psychology, 21(3), 233-248.

Kweon, B. S. Ellis, C. D. Leiva, P. I. \& Rogers, G. O. (2010). Landscape components, land use, and neighborhood satisfaction, Environment and Planning B: Planning and Design, 37(3), 500-517.

Kyle, G. Graefe, A. Manning, R. \& Bacon, J. (2004). Effect of activity involvement and place attachment on recreationists' perceptions of setting density, Journal of Leisure Research, 36(2), 209-231.

Lang, J. (1994). Urban design: the American experience. John Wiley \& Sons. Lang, J. T. (1987). Creating architectural theory: The role of the behavioral sciences in environmental design ( $p$. 205). New York: Van Nostrand Reinhold.

Lee, S. M. Conway, T. L. Frank, L. D. Saelens, B. E. Cain, K. L. \& Sallis, J. F. (2017). The relation of perceived and objective environment attributes to neighborhood satisfaction. Environment and Behavior, 49(2), 136-160. 
Analysis of The Effects of Open Place Performance on Users' Satisfaction Using Post-Occupancy Evaluation

Lovejoy, K. Handy, S. \& Mokhtarian, P. (2010). Neighborhood satisfaction in suburban versus traditional environments: An evaluation of contributing characteristics in eight California neighborhoods, Landscape and Urban Planning, 97(1), 37-48.

Madureira, H., Nunes, F., Oliveira, J. \& Madureira, T. (2018). Preferences for urban green space characteristics: a comparative study in three portuguese cities, Environments, (5) 23.

Mazumdar, S. \& Mazumdar, S. (2004). Religion and place attachment: A study of sacred places, Journal of Environmental Psychology, 24(3), 385397.

Mumcu, S., Yılmaz, S. \& Düzenli, T. (2017). Açık mekanlardaki oturma donatılarının ve yerlerinin tasarımına ilişkin faktörler, İnönü Üniversitesi Sanat ve Tasarım Dergisi, 7(15), 1-16.

Özkan, D. G. (2011). Kentsel açık mekanlarda kullanım sonrası değerlendirme: trabzon sahil bandı örneği (Yüksek Lisans Tezi), Karadeniz Teknik Üniversitesi Fen Bilimleri Enstitüsü, Trabzon.

Özkan, D. G. \& Yilmaz, S. (2019). The effects of physical and social attributes of place on place attachment: a case study on Trabzon urban squares. Archnet-IJAR: International Journal of Architectural Research, 13(1), 133-150.

Özkan, D. G., Alpak, E. M., Yilmaz, S., Düzenli, T. \& Ozbilen, A. (2015). post occupancy evaluation and user satisfaction in urban open place, Fresenius Environmental Bulletin, 24(5), 1659-1672.

Preiser, W. F. (2001). The evolution of post-occupancy evaluation: Toward building performance and universal design evaluation, Learning from our buildings a state-of-the practice summary of post-occupancy evaluation. National Academy Press.

Preiser, W. F. E., Rabinowitz, H. R. \& White, E. T. (1988). Post Occupation Evaluation. Van NostrandReinhold, New York, London, Melbourne.

Preiser, W. F. \& Nasar, J. L. (2008). Assessing building performance: Its evolution from post-occupancy evaluation, International Journal of Architectural Research: ArchNet-IJAR, 2(1), 84-99.

Project for Public Places (Ed.). (2000). How to turn a place around: a handbook for creating successful public places. Project for Public Places Incorporated.

Ramkissoon, H., Smith, L. D. G. \& Weiler, B. (2013a). Testing the dimensionality of place attachment and its relationships with place satisfaction and pro-environmental behaviours: A structural equation modelling approach. Tourism management, 36, 552-566.

Ramkissoon, H., Smith, L. D. G. \& Weiler, B. (2013b). Relationships between place attachment, place satisfaction and pro-environmental 
behaviour in an Australian national park, Journal of Sustainable Tourism, 21(3), 434-457.

Salama, A. (2018). Neo-liberalism and the Architecture of the Post Professional Era. Sadri,H.(Ed.), Post-professional Architecture and Academia(p.271).

Salama, A. M. \& Azzali, S. (2015). Examining attributes of urban open places in Doha. Proceedings of the Institution of Civil Engineers-Urban Design and Planning, 168(2), 75-87.

Salama, A. M., Remali, A. M. \& MacLean, L. (2017). Characterisation and systematic assessment of urban open places in Glasgow city centre. Spatium, 22-33.

Shehab, N. \& Salama, A. M. (2018). The spatiality of segregation: narratives from the everyday urban environment of Gothenburg and Glasgow, ArchNet-IJAR: International Journal of Architectural Research, 12(1), 71-90.

Sirgy, M. J. (2010). Toward a quality-of-life theory of leisure travel satisfaction, Journal of Travel Research, 49(2), 246-260.

Stedman, R. C. (2002). Toward a social psychology of place: Predicting behavior from place-based cognitions, attitude, and identity. Environment and Behavior, 34(5), 561-581.

Whyte, H.W. (2000). How to Turn a Place Around, Projects for Public Place, p. 52, New York, NY.

Whyte, W. H. (1980). The social life of small urban places. Project for Public Spaces.

Williams, D. R. \& Vaske, J. J. (2003). The measurement of place attachment: Validity and generalizability of a psychometric approach. Forest Science, 49(6), 830-840.

Zorlu, F. (2008). Kentsel doku-ulaşım sistemi ilişkileri, Metu Journal of The Faculty of Architecture, 25(1).

\section{Resume}

Doruk Görkem Özkan received his BSc in Landscape Architecture from Karadeniz Technical University (KTU) in 2008. Also he received his MA and Ph.D. in Landscape Architecture from Karadeniz Technical University in 2012 and 2017, respectively. Currently, he is a Associate Professor of Landscape Architecture, Landscape Planning and Design the Karadeniz Technical University and his research interests include landscape design, environmental psychology, place attachment, proenvironmental behaviour. He is a member of KTU Environmental Problems Research and Application Center, Natural structures and landscape working group.

Duygu Akyol received her BSc in Landscape Architecture from Ege University in 2012 and Master Education was completed in Dokuz Eylül University City and 
Analysis of The Effects of Open Place Performance on Users' Satisfaction Using Post-Occupancy Evaluation

Regional Planning Department in 2015. Currently, she is continuing her PhD education at Karadeniz Technical University Landscape Architecture Department and she is a Research Assistant at Karadeniz Technical University. Her research interests include landscape design, urban design and planning and geodesign 